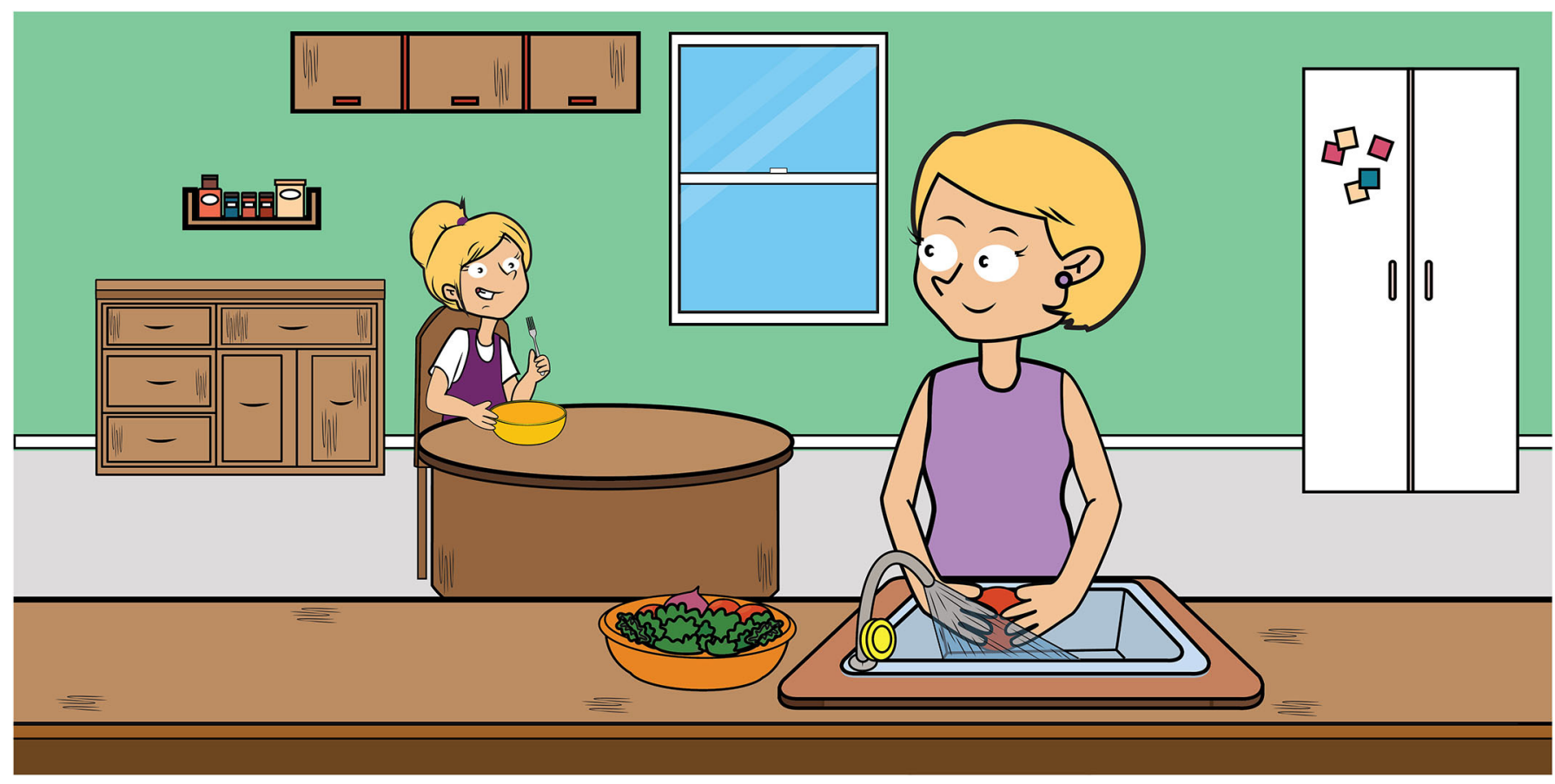

\title{
THE FARM-TO-FORK JOURNEY: KEEPING PRODUCE FRESH AND SAFE TO EAT
}

\section{Alice Pierce, Joseph Student and Maeli Melotto*}

Department of Plant Sciences, University of California, Davis, Davis, CA, United States

YOUNG REVIEWER:

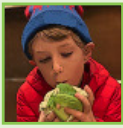

$\mathrm{NOAH}$

AGE: 10
FRESH PRODUCE

farm-produced

crops that are raw or

minimally processed.
Fruits and vegetables are nutritious and help you stay healthy. Yet, they might not be safe to eat right after you purchase them. The farm-to-fork journey includes all the stages your produce goes through, from growing the plants to being eaten in your home. It is important to maintain freshness of the fruits and vegetables and prevent microbial contamination of produce throughout the farm-to-fork journey. At home, you must follow the guidelines provided on the food's packaging, or simply wash your fruits and vegetables well. In this article, we will walk you through five stages in the farm-to-fork journey: production, processing, distribution, retail, and consumer. We will also discuss where food can become contaminated. At the end of the article, we will give you some ideas of what you can do at home to prevent getting sick.

\section{FARM-TO-FORK}

We have all heard how important it is to eat fresh fruits and vegetables. Fresh produce provides energy and nutrients that keep us 
MICROORGANISMS

Organisms, including bacteria, viruses, fungi, and parasites, that are too small to see with the naked eye. Many do no harm, but others can cause diseases.

\section{PATHOGEN}

CONTAMINATION

The accidental introduction of microorganisms that make us sick into a product, such as a food.

\section{FOOD SAFETY}

Proper handling, preparing, cooking, and storing of food to prevent foodborne illnesses

\section{READY-TO-EAT}

FOOD

A food product that can be eaten raw or with little processing

\section{FARM-TO-FORK} JOURNEY

The journey food takes to get to your table. Stages include production, cleaning and packaging, distribution, retail, and consumer healthy. Among other functions, the nutrients in fruits and vegetables strengthen the immune system to help us fight off diseases. Can you list any nutrients contained in fresh produce? Here are a few you should add to your list: carbohydrates, protein, vitamins, minerals, fiber, starch, and substances called phytochemicals. But did you know that fresh produce might also contain microorganisms that can make you sick? They are called pathogens. Because of the possibility of pathogen contamination, food safety is extremely important. To ensure that your fresh food is safe to eat, food products need to be handled, prepared, cooked, and stored carefully. Certain foods, such as ready-to-eat (RTE) produce, need extra attention and must be handled according to safety instructions before eating. RTE foods are products that can be eaten raw or with little processing, straight out of the package. RTE foods do not need to be cooked before you eat them [1]. For example, think of the prepacked salads, leafy vegetables (such as lettuce and spinach), and fruits that you can buy at the grocery store. Can you think of examples of RTE food you have at home? All these foods have a combination of the healthy nutrients listed above because their freshness is maintained throughout the farm-to-fork journey.

Do you know what the farm-to-fork journey is? It includes all the stages that food goes through to reach your home, from the planting and harvesting of fruits and vegetables to their arrival on your plate (Figure 1). During this journey, the goal is for these produces to remain fresh and free of microorganisms that could make you sick. The pathogens that could contaminate your food include bacteria (Escherichia coli, Salmonella, Listeria), fungi, parasites, and viruses. However, there are measures taken along the journey to help prevent microbial contamination. In this article, we describe how produce remains fresh during the farm-to-fork journey. We also talk about the potential steps where your RTE food might encounter pathogens and how this contamination can be avoided. Last, we give you tips on what you can do at home to prevent getting sick.

\section{PRODUCTION}

The first step in the farm-to-fork journey is production. You might know the production stage as the farm. At this stage, seeds are planted across the field and grown to become mature plants. The plants eventually produce the fruits and vegetables we eat. An irrigation system waters the plants to help them grow. Farm workers may apply pesticides so that bugs do not eat or damage the plants. Workers also apply nutrients (fertilizers) so that the plants grow well and stay healthy.

There are many parts of the production step where produce might become contaminated. The soil in which the plants are grown, fertilizers, soil additives such as manure, the water used 
Figure 1

The farm-to-fork journey. There are five main steps in the journey of RTE produce, from farm to fork: (A) production, (B) cleaning and packaging, (C) distribution, (D) retail, and (E) consumer. To avoid pathogen contamination of produce, it is very important that safety precautions are taken at each step.

\section{CROSS-}

\section{CONTAMINATION}

The transfer of pathogens between surfaces that are in direct contact with each other.

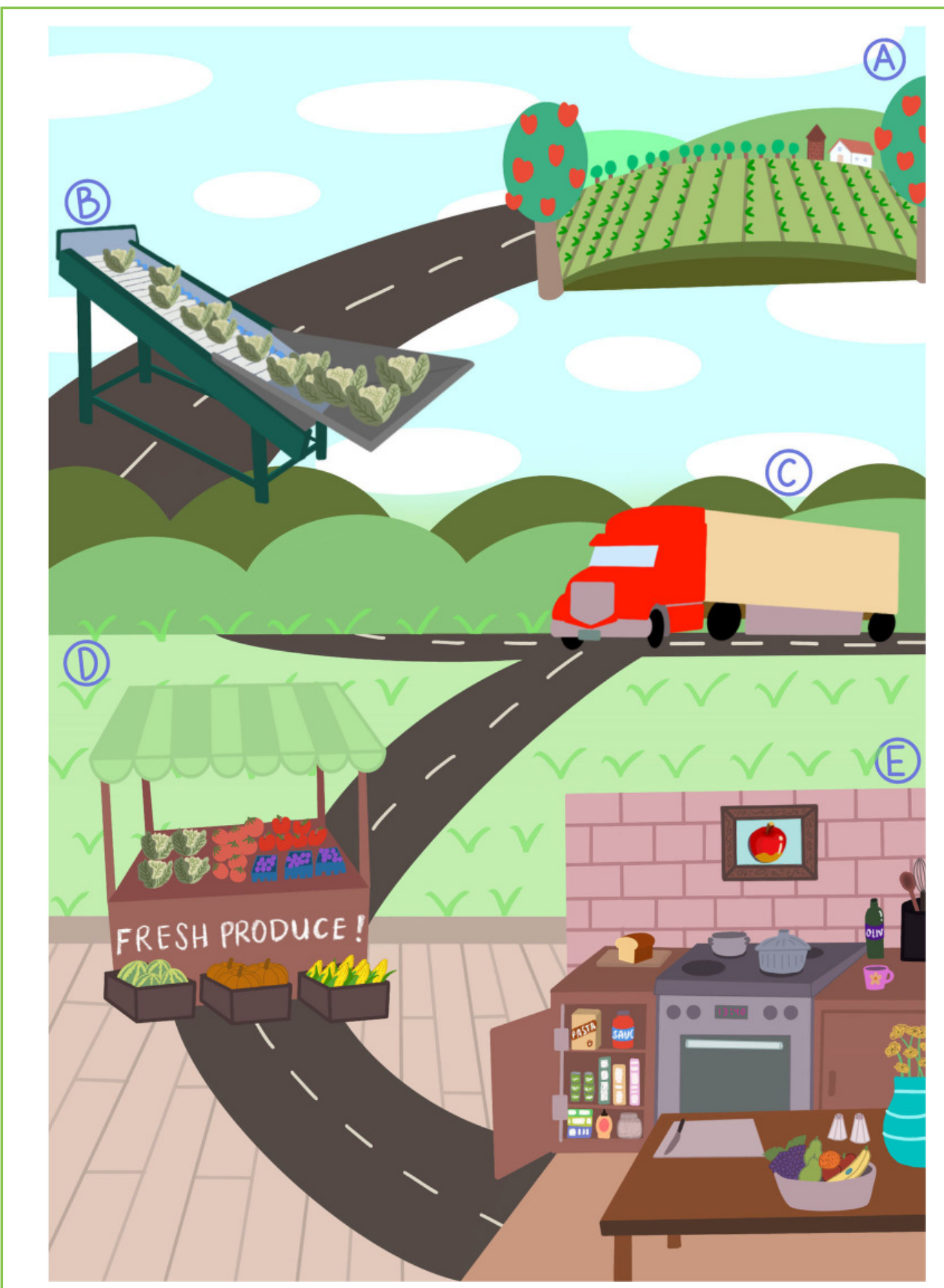

Figure 1

for irrigation, or pesticides could contain harmful microorganisms that could contaminate the plants [2]. Sick workers could also contaminate the produce [3]. Additionally, plant-to-plant contact could spread pathogens among the plants [4]. Farm workers worry about this cross-contamination since it can make all their produce contaminated with pathogens. But do not worry! When handling fruits and vegetables, farmers follow a set of rules described in a document called Good Agricultural Practices. Following these guidelines reduces potential contamination of produce in the field. 
When ready, fruits and vegetables are harvested by hand or mechanically. Workers make sure that the produce is good by checking if it is cut or bruised. It is very important that the produce remains fresh throughout the farm-to-fork journey because fresh fruits and vegetables have the maximum nutritional content.

\section{CLEANING AND PACKAGING}

After the produce is harvested, it must be cleaned and packaged before it is shipped to the grocery store. Fruits and vegetables are transported to factories to be processed. First, all produce is carefully washed with cleaning agents. Washing the produce removes leftover soil, chemicals, or pathogens that might be on its surface [5]. If the fruits and vegetables are not washed properly, pathogens may survive on their surfaces for a long time.

After being cleaned, the fruits and vegetables are cut, dried, smoked, fermented, or left as-is, depending on the desired final product. Then, the foods may be packaged into containers such as cans, jars, or plastic wraps. Proper packaging prevents pathogens from getting into the package and contaminating the food. Whole fruits and vegetables that are cleaned but not packaged are put into boxes to be sold as bulk produce.

Cleaning and packaging ensure that the food remains fresh and uncontaminated. These processes are done with a lot of attention, to meet the standards of cleanliness and freshness described in a document called Current Good Manufacturing Practices (CGMP). This document describes steps to prevent potential contamination of produce during the cleaning and packaging stage.

\section{DISTRIBUTION}

The distribution step consists of transportation and storage of products. After they are cleaned, RTE foods are placed into a vehicle, such as a truck. The truck must be at a temperature that ensures the products will remain fresh and safe to eat. Improper refrigeration temperatures can cause produce to go bad or can even cause the growth of any remaining bad microorganisms [5]. The food is delivered to warehouses where the products are prepared for distribution to grocery stores. Improper conditions in the warehouse, such as temperatures that are too warm or too much moisture in the air, contribute to spoilage and microbial growth. Warehouses also follow CGMP, to keep produce safe. 
Figure 2

Child preparing food under adult supervision. In the kitchen, it is important to take the necessary steps to prevent foodborne illnesses while prepping and cooking food, including the wash of cooking utensils and cutting boards with hot soapy water before and after handling raw food, as well as cutting and disposing of damaged areas of fruits and vegetables.

Additionally, children must be supervised by an adult to prevent injuries.

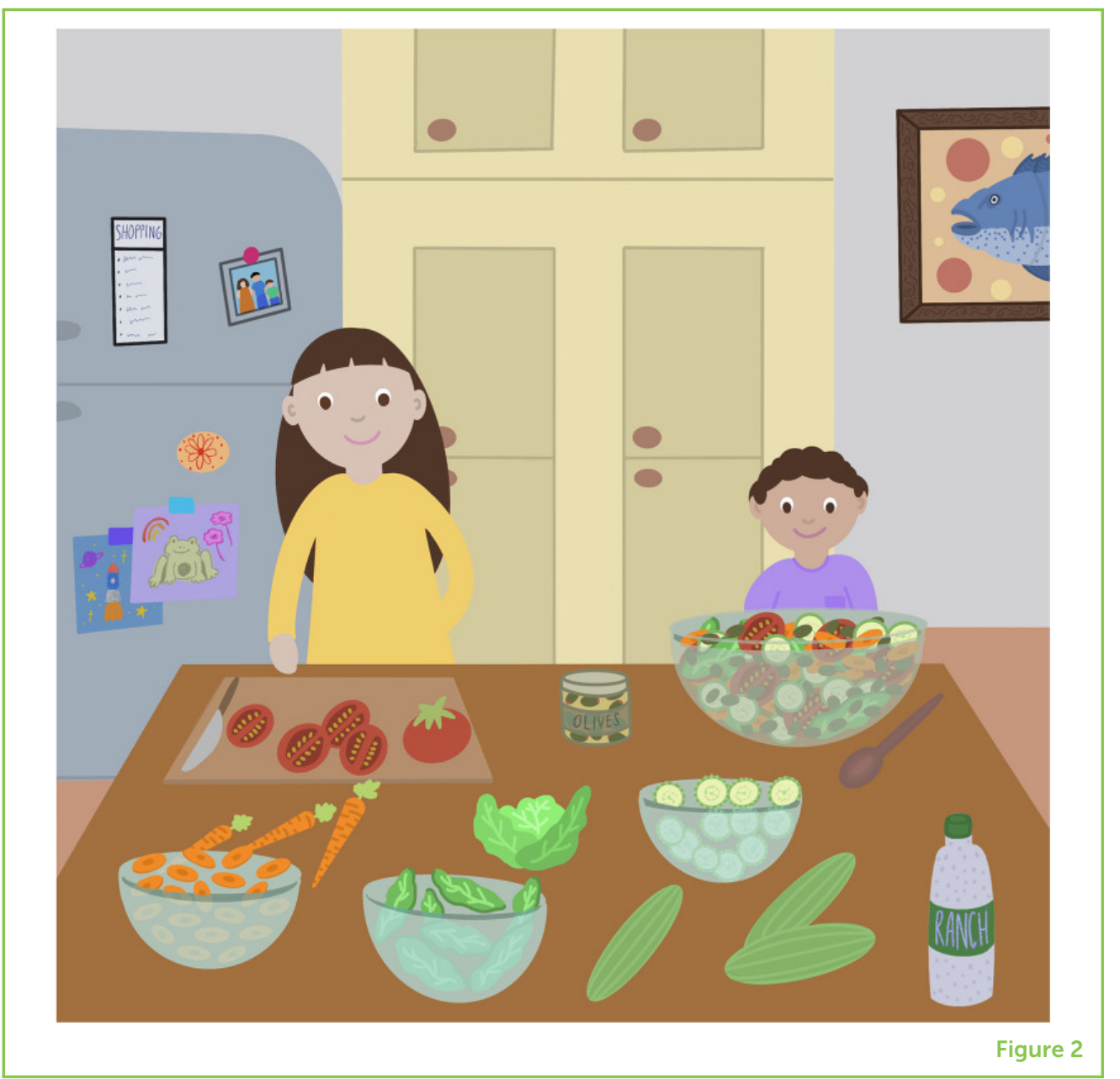

\section{RETAIL}

After the foods have been delivered to grocery stores, they are placed on shelves to be sold. As you might have noticed in your local grocery store, food products are carefully placed to avoid any spoilage or contamination. Do you remember the different aisles in your store? There are aisles for canned products, pasta, juices, dairy products, meat and deli, and desserts. RTE foods are placed on refrigerated shelves and sold by their sell-by date. Fresh produce that has not been prepackaged is placed in the produce section, where customers can pick and choose fruits and vegetables to their liking.

\section{CONSUMER}

The consumer step, also known as the fork step, is when you take the food products home to prepare and eat them. It is important to keep food fresh to obtain the highest amount of nutrition from it. To keep produce fresh, we must make sure that fruits and vegetables are stored in the right environment. Every RTE foods need different temperatures and humidity levels to remain fresh and safe to eat. You 
can look in books or online to learn how to store your produce and RTE foods properly.

Even in your own kitchen, there are ways that RTE foods can become contaminated. It is very important to take all necessary steps to prevent foodborne diseases at home (Figure 2). For example, RTE foods can be cross-contaminated with raw meat, poultry, or seafood that is being prepared at the same time. Improperly washed cooking utensils and cutting boards are another possible source of contamination. If you do not wash your hands before handling food, you could transfer pathogens from your hands to your food. Dishcloths and sponges that have been used and left moist for a while also can retain pathogens and contaminate utensils.

Here the farm-to-fork journey is complete. Learning about the farm-to-fork chain is not only important to understand where the food we consume comes from, but also to help us understand how easily the food may become contaminated along the way. This knowledge also helps us to understand that food borne illnesses can be prevented by following manufacturer's instructions, good hygiene, and washing raw fruits and vegetables before they are consumed.

\section{ACKNOWLEDGMENTS}

Research in the Melotto Lab was supported by grants from the U.S. Department of Agriculture-National Institute of Food and Agriculture (USDA-NIFA; 2015-67017-23360, 2017-67017-26180, and 2020-67017-30779) and NIFA Hatch grant (CA-D-PLS-2327-H).

\section{REFERENCES}

1. Elviss, N. C., and Jørgensen F. 2012. "Investigations prompted by the discovery of high levels of Salmonella in fresh herbs in the UK," in Case Studies in Food Safety and Authenticity, ed J. Hoorfar (Cambridge: Woodhead Publishing). p. 116-22. doi: 10.1533/9780857096937.2.116

2. Center for Disease Control and Prevention. Food Safety. CDC. Available online at: https://www.cdc.gov/foodsafety/index.html (accessed June 23, 2020).

3. Machado-Moreira, B., Richards, K., Brennan, F., Abram, F., and Burgess, C. M. 2019. microbial contamination of fresh produce: what, where, and how? Compr. Rev. Food Sci. Food Saf. (2019) 18:1727-50. doi: 10.1111/1541-4337.12487

4. Gombas, D., Luo, Y., Brennan, J., Shergill, G., Petran, R., Walsh, R., et al. 2017. Guidelines to validate control of cross-contamination during washing of fresh-cut leafy vegetables. J. Food Prot.

80:312-30. doi: 10.4315/0362-028X.JFP-16-258

5. Kotzekidou, P. 2016. "Factors influencing microbial safety of ready-to-eat foods" in Food Hygiene and Toxicology in Ready-to-Eat Foods, ed P. Kotzekidou 
(Cambridge, MA: Academic Press). p. 33-50. doi: 10.1016/B978-0-12-8019160.00003-0

SUBMITTED: 24 July 2020; ACCEPTED: 07 February 2022;

PUBLISHED ONLINE: 03 March 2022.

EDITOR: Valerie Gerriets, California Northstate University, United States

SCIENCE MENTOR: Alison K. Ventura

CITATION: Pierce A, Student J and Melotto M (2022) The Farm-to-Fork Journey: Keeping Produce Fresh and Safe to Eat. Front. Young Minds 10:587135. doi: 10. 3389/frym.2022.587135

CONFLICT OF INTEREST: The authors declare that the research was conducted in the absence of any commercial or financial relationships that could be construed as a potential conflict of interest.

COPYRIGHT @ 2022 Pierce, Student and Melotto. This is an open-access article distributed under the terms of the Creative Commons Attribution License (CC BY). The use, distribution or reproduction in other forums is permitted, provided the original author(s) and the copyright owner(s) are credited and that the original publication in this journal is cited, in accordance with accepted academic practice. No use, distribution or reproduction is permitted which does not comply with these terms.

\section{YOUNG REVIEWER}

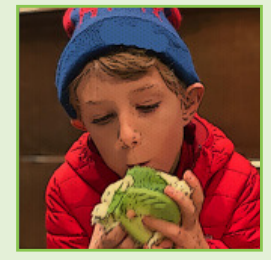

\section{NOAH, AGE: 10}

I am a 10 year old kid named Noah. I like to code and read during my free time, and can type at over 40 words per minute. I like to play the piano, and know two guitar chords. My favorite song to play is "Turkish March," by Ludwig van Beethoven. When I grow up, I did like to become a teacher.

\section{AUTHORS}

\section{ALICE PIERCE}

I am a junior specialist in the Melotto Lab at the University of California, Davis. My love for plants was sparked during my second year of college, and since then I have been involved in plant research. I am interested in learning how plants interact with their environments, including how plants associate with the microorganisms around them. Specifically, I would like to understand the genetic factors that influence a plant's adaptation and survival in response to different stressors. In my free time, I enjoy making illustrations and playing video games. 

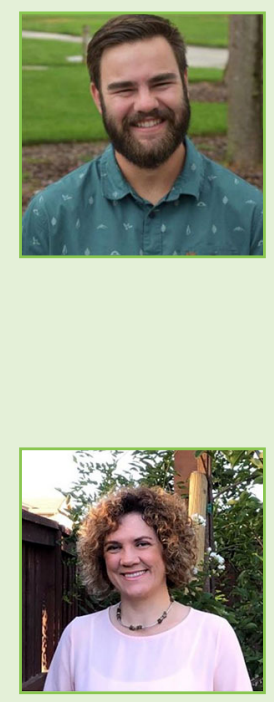

\section{JOSEPH STUDENT}

I am a junior specialist in the Melotto Lab at the University of California, Davis. I discovered my love of plants during my second year at Eckerd College and have been captivated by them ever since. What interests me the most is how plants interact with and adapt to their environments, including the microorganisms around them. In the future, I would like to understand how plants evolve to live in changing environments and deal with different stressors. I like to relax by reading, skiing, and playing video games.

\section{MAELI MELOTTO}

I am a professor in the Department of Plant Sciences at the University of California, Davis. I knew I wanted to work with plants since I was an undergraduate majoring in biology. Throughout my career, I researched plant interactions with microorganisms, focusing on plant pathogens that cause plant diseases and human pathogens that causes foodborne illnesses. I use scientific tools and technologies to lessen these problems and ensure the production of healthy and nutritious foods that are safe to eat. When I am not working, I like to play the piano, sew, and take care of my garden.

*melotto@ucdavis.edu 